Re-examining the rare and the lost : a review of fossil Tortricidae (Lepidoptera)

\title{
Heikkilä, Maria
}

2018-03-13

Heikkilä, M , Brown , J W , Baixeras , J , Mey , W \& Kozlov , M V 2018 , ' Re-examining the rare and the lost : a review of fossil Tortricidae (Lepidoptera) ' , Zootaxa , vol. 4394 , no. 1 , pp. 41-60 . https://doi.org/10.11646/zootaxa.4394.1.2

http://hdl.handle.net/10138/234022

https://doi.org/10.11646/zootaxa.4394.1.2

cc_by

publishedVersion

Downloaded from Helda, University of Helsinki institutional repository.

This is an electronic reprint of the original article.

This reprint may differ from the original in pagination and typographic detail.

Please cite the original version. 


\title{
Re-examining the rare and the lost: a review of fossil Tortricidae (Lepidoptera)
}

\author{
MARIA HEIKKILÄ $\ddot{A}^{1,6}$, JOHN W. BROWN ${ }^{2}$, JOAQUIN BAIXERAS 3 , \\ WOLFRAM MEY ${ }^{4}$ \& MIKHAIL V. KOZLOV ${ }^{5}$ \\ ${ }^{I}$ Finnish Museum of Natural History, Zoology Unit, FI-00014 University of Helsinki, Finland. E-mail: maria.heikkila@helsinki.fi \\ ${ }^{2}$ National Museum of Natural History, NHB E-516 MRC 168, Washington, DC 20013-7012, U.S.A. \\ E-mail: tortricidae.jwb@gmail.com \\ ${ }^{3}$ Cavanilles Institute of Biodiversity and Evolutionary Biology, University of Valencia, C/Catedrático José Beltran, 2, 46980 Valencia, \\ Spain.E-mail: joaquin.baixeras@uv.es \\ ${ }^{4}$ Museum für Naturkunde, Leibniz-Institut für Evolutions- und Biodiversitätsforschung, Invalidenstrasse, 43, D-10115 Berlin, Ger- \\ many.E-mail:wolfram.mey@mfn-berlin.de \\ ${ }^{5}$ Section of Ecology, Department of Biology, University of Turku, FI-20014 Turku, Finland. E-mail: mikoz@utu.fi \\ ${ }^{6}$ Corresponding author
}

\begin{abstract}
We re-evaluate eleven fossils that have previously been assigned to the family Tortricidae, describe one additional fossil, and assess whether observable morphological features warrant confident assignment of these specimens to this family. We provide an overview of the age and origin of the fossils and comment on their contribution towards understanding the phylogeny of the Lepidoptera. Our results show that only one specimen, Antiquatortia histuroides Brown \& Baixeras gen. and sp. nov., shows a character considered synapomorphic for the family. Six other fossils (Electresia zalesskii Kusnezov, 1941; Tortricidrosis inclusa Skalski, 1973; Tortricites skalskii Kozlov, 1988; Tortricibaltia diakonoffi Skalski, 1992; Polyvena horatis Poinar and Brown, 1993 and a trace fossil purported to be larval feeding damage of Retinia resinella (Linnaeus, 1758)) exhibit a combination of homoplastic characters typical of tortricid moths or characteristic feeding damage. An unnamed species doubtfully assigned to Olethreutinae by Skalski (1992), Spatalistiforma submerga Skalski, 1992, Tortricites florissantanus (Cockerell, 1907), Tortricites destructus (Cockerell, 1916) and Tortricites sadilenkoi Kozlov, 1988 do not show enough character evidence to be convincingly placed in Tortricidae. Therefore, we transfer the three latter species from the collective group Tortricites Kozlov, 1988, defined as an assemblage of fossil leafrollers that cannot be placed with certainty in known genera, to Paleolepidopterites Kozlov, new collective group, defined as a group of fossil lepidopterans whose assignment to a certain family is currently impossible.
\end{abstract}

Key words: Amber, fossil record, Antiquatortia, Electresia, Paleolepidopterites, Polyvena, Retinia, Spatalistiforma, Tortricibaltia, Tortricidrosis, Tortricites

\section{Introduction}

Leafroller moths (Tortricidae) are a large lepidopteran family of nearly 11000 described species (Gilligan et al. 2014). The family has a worldwide distribution with greatest species diversity in the New World tropics (Brown 2005). Many tortricid larvae roll the leaves of the host plant as a shelter, but the family also includes gall-inducers, root-borers, seed-predators, fruit-borers, flower-feeders, and leaf-tiers, and some lineages exhibit more unusual feeding strategies (Powell et al. 1998). Many leafrollers are economically important pests (Powell \& Brown 2012). Despite the considerable species richness of the family, Tortricidae have been poorly preserved as fossils, and the identification of these, as that of many other fossil Lepidoptera, is contentious. More generally, the fossil record of Lepidoptera is considerably poorer than that of other large insect groups, and a significant proportion of fossil Lepidoptera is suspected to have been identified based only on superficial similarity to extant species rather than apomorphic characters or reliable diagnostic character combinations (Kristensen \& Skalski 1998; Sohn et al. 2012; Sohn et al. 2015). 
The scales of Lepidoptera, which are the source of the name of the order ( $\lambda \varepsilon \pi_{i}^{i} \zeta$ (lepis) in Ancient Greek $=$ scale; $\pi \tau \varepsilon \rho o ́ v$ (pteron) in Ancient Greek = wing), often hide diagnostic features, such as wing venation, that are useful in assigning species to broad taxonomic groups. But perhaps the most important source of diagnostic characters, the morphological features of the genitalia, typically requires dissection to reveal them. In fossil Lepidoptera (compression and amber fossils) it is sometimes difficult to observe and/or interpret the wing venation and usually impossible to observe the genitalia. Hence, identifications of most fossil Lepidoptera are based on superficial similarities to extant species rather than on apomorphies (i.e. shared derived characters) or reliable character combinations (Kristensen \& Skalski 1998; Sohn et al. 2012). These unreliable identifications may result in a misleading picture of the age of the different lineages and of the historical distribution of certain groups (Horak 1998).

With the growing popularity of using fossils as calibration points in divergence time analyses (de Jong 2017), concern over the reliability of identifications has been expressed, and the need to use authoritatively identified fossils has been emphasized (e.g. Parham et al. 2012). A more reliable picture of the fossil record of Lepidoptera would lead to a better understanding of the fauna of the past and when different lineages have originated and diversified.

The present study is part of a large international effort to critically re-examine known fossil Lepidoptera and gain a better understanding of the state of the fossil record of the entire order. The study is part of a project coordinated by the first author and includes a large number of collaborators with expertise in different groups of Lepidoptera. Using the most recent information on the systematics of Lepidoptera or subgroups, combined with thorough re-examination of known fossils specimens, the project seeks to clarify and correct past identifications and establish a new basis and criteria for future work on fossil Lepidoptera. Reviews on fossil Nepticulidae (Doorenweerd et al. 2015) and Papilionoidea (de Jong 2017) have already been published, and several reviews on fossils currently placed in other superfamilies are in preparation.

Sohn et al. $(2012,2015)$ listed 82 fossil specimens assigned to Tortricidae. However, only 11 of these specimens are known to ever have been studied in detail, and only 9 of them were described and named prior the beginning of our study. Eight of these have been placed in extant subfamilies (Chlidanotinae, Olethreutinae, or Tortricinae), and two are assigned to extant genera. Our ultimate goal is to verify and/or reassess whether these assignments are based on convincing evidence and determine if some of these fossils could be used as calibration points in divergence time analyses.

\section{Material and methods}

Institutional abbreviations:

AMNH American Museum of Natural History, New York, U.S.A.

FMNH Field Museum of Natural History, Chicago, Illinois, U.S.A.

MNHU Berlin Museum of Natural History (= Museum für Naturkunde Berlin), Berlin, Germany.

MZH Finnish Museum of Natural History (= Luonnontieteellinen keskusmuseo LUOMUS, Helsingin yliopisto), Helsinki, Finland.

PIRAS Paleontological Institute, Russian Academy of Sciences (= Палеонтологический институт РAH), Moscow, Russia

UCNH University of Colorado Museum of Natural History, Boulder, Colorado, U.S.A.

USNM United States National Museum of Natural History, Washington, DC, U.S.A.

ZMCD Zoological Museum, Natural History Museum of Denmark, University of Copenhagen (= Zoologisk Museum, Statens Naturhistoriske Museum, Københavns Universitet), Copenhagen, Denmark.

Abbreviations of authors' names:

JB Joaquín Baixeras

JWB John W. Brown

MH Maria Heikkilä 
Age of fossil specimens. The ages of the fossils given in the present study follow the recent estimates presented in Sohn et al. (2012) and references therein. The earliest evidence of the family comes from Baltic amber dated to the Lutetian, Middle Eocene (mean \pm S.E.: $48.6 \pm 0.2-40.4 \pm 0.2 \mathrm{Ma}$ ). Most of the fossil tortricids listed in Sohn et al. (2012) are from this period. There are only two known compression fossils, both from the Florissant formation, Colorado (late Priabonian, late Eocene: $33.9 \pm 0.1 \mathrm{Ma}$ ). Three of the known fossil specimens are in Dominican amber (Burdigalian, Early Miocene: 23.03-20.43 Ma) and one is in Mexican amber (ChattianAquitanian, Late Oligocene-Early Miocene boundary: $23.03 \mathrm{Ma}$ ). Three of the fossils are relatively recent, two are dated to the Pleistocene: one specimen in East African copal and the other possible larval feeding damage on a branch from a peat bog, the third is in copal of unknown age and origin.

Specimens examined. Of the 82 potential tortricid fossils listed in Sohn et al. (2012), we had access to only five amber fossils, one compression fossil and the trace fossil. Two of the amber fossils (Antiquatortia histuroides Brown \& Baixeras, gen. nov. and sp. nov. and Spatalistiforma submerga Skalski, 1992) and the compression fossil Tortricites destructus (Cockerell, 1916) were examined and photographed at the USNM. A fourth amber fossil, Tortricidrosis inclusa Skalski, 1973 and a new fossil specimen regarded as conspecific with it were examined at the MNHU, and the sixth inclusion, Electresia zalesskii Kusnezov, 1941 was examined at the PIRAS. Polyvena horatis Poinar and Brown, 1993, a fossil in Dominican amber, was examined closely by one of the authors (JWB) of this paper. The compression fossil, Tortricites florissantanus (Cockerell, 1907), was examined from recent high-quality photographs provided by the UCNH. The branch from Pleistocene peat with larval feeding damage attributed to Retinia (Evetria), a genus known as "pitch nodule makers" (Turnock 1953), was examined at LUOMUS.

Unfortunately, in spite of all our efforts, the repository remains unknown for 68 of the putative 82 fossil tortricid specimens. For example, it is not known where the amber fossil specimens mentioned by Gravenhorst (1835) (ca. 40 specimens, probably only part of which are tortricids) or Menge (1856) (26 fossil tortricids) are today. A large part of Gravenhorst's collection was lost during World War II (Prof. M. Wanat, Museum of Natural History University of Wroclaw, pers. comm.). This also seems to have been the unfortunate fate of the Menge collection (Prof. R. Szadziewski, Gdańsk University, pers. comm.). The original publications do not provide enough information to assess with certainty whether these fossils belong to Tortricidae. The lack of text and illustrations also makes verifying the identification of the following three fossil specimens impossible. Skalski (1976) listed a specimen of Rhopobota in copal, but the publication does not contain any further information or indicate where it is deposited. A tortricid in Mexican amber is mentioned by Skalski (1973) without additional information. We do not have any leads on the current location of these two specimens. A fossil tortricid in Dominican amber mentioned by Poinar (1992) resides in a private collection, and we were unable to access it or obtain photographs of it.

A fossil in Baltic amber, Tortricites sadilenkoi Kozlov, 1988, was in the private collection of K. M. Sadilenko, Moscow, Russia, until it was stolen. However, MVK has photographs, illustrations and notes on the specimen, and these data are included in the present paper. Two fossils in Baltic amber, Tortricibaltia diakonoffi Skalski, 1992 and a possible olethreutine (Skalski, 1992), could not be located at the FMNH, which was indicated as the repository of these specimens in the original publication. A fourth specimen in Baltic amber, Tortricites skalskii Kozlov, 1988, was not located at the PIRAS (Prof. A. Rasnitsyn, pers. comm.). To assess the taxonomic placement of the four aforementioned fossils, we rely solely on the information provided in the original publications.

In summary, nine fossils were re-examined firsthand or from recent good quality photographs, and four using available literature.

Specimen observation. Fossils were examined with a Leica MZ 12 or similar stereomicroscopes. Fossils in amber were immersed in glycerol and digital images were captured using a Canon EOS 5D camera mounted in a B.-K. visionary imaging system. The compression fossil was photographed using the same system, but without glycerol. Wing venation nomenclature follows Horak (1984).

Diagnostic characters. Although the monophyly of Tortricidae is widely accepted and strongly supported by molecular and morphological data (Regier et al. 2012; Heikkilä et al. 2015; Fagua et al. 2017), very few morphological characters have been recognized as diagnostic of this clade. Putative synapomorphies include one female character and three larval characters (Powell \& Brown 2012): flat papillae anales facing ventrally in the 
female genitalia; presence of the D2 seta on a shared dorsal pinaculum on A9 in the larva; the presence of a morphologically distinct anal fork (secondarily lost in some internal feeders) in the larva; and the anterior, slightly dorsoanterior or ventroanterior position of the SD1 seta with regard to the spiracle on A8 in the larva. Because tortricid fossils are typically adults and the papillae anales can rarely, if ever, be seen, identifying fossils as Tortricidae must be based on a combination of characters rather than convincing apomorphies. Characters often found together (but none of which is unique to Tortricidae) include the presence of chaetosemata and ocelli; the characteristic usually porrect, rough-scaled labial palpi (with modifications); and the wing shape and venation with all veins present and separate beyond the discal cell (but with many minor modifications). Horak (1998) also mentioned the upwardly oriented scales on lower half of frons as a feature characteristic of Tortricidae.

Because many microlepidopteran families can be identified convincingly by morphological features of the head alone, i.e., a combination of the antennae, labial palpi, maxillary palpi, haustellum, and ocelli, an intact head of a fossil microlepidopteran provides a good foundation for a "process of elimination" strategy. That is, although we are unable to identify a convincing synapomophy for including a fossil in Tortricidae, we may be able to exclude the fossil from related microlepidoptera families that may otherwise be confused superficially with tortricids. For example, members of Pyraloidea, Gelechioidea, and Choreutidae all have a scaled haustellum, so the presence of this character immediately excludes a fossil from Tortricidae. Likewise, large, upturned labial palpi characteristic of most Gelechioidea are not present in Tortricidae. Other features of the head, such as scaling of the vertex, bristles from the labial palpus (e.g., many Tineidae), and presence/absence of ocelli are helpful, especially in combination, but not diagnostic. Finally, the presence of chaetosemata (when visible) is a fairly good character for distinguishing tortricids from other microlepidoptera families.

Although this approach is less than perfect, it may be the best we can do. Because the assignment of extant tortricids to any taxonomic level almost always requires the examination of the genitalia, and genitalia cannot be examined in the vast majority of fossils, we opt for a conservative approach and make a decision whether or not the fossil can be assigned to the family rather than trying to place it in some lower taxonomic level.

Based on our observations and evidence provided in literature, we group the fossils into two categories:

Fossils most likely belonging to Tortricidae: these fossils show a character combination diagnostic of extant Tortricidae (see above).

Fossils most likely not belonging to Tortricidae or character evidence is too meagre: these fossils are too poorly preserved to confirm presence of characters typical of Tortricidae or such characters are not present.

Under each of the two categories, the fossils are discussed in chronological order, from oldest to youngest, and fossils of comparable age are in chronological order based on the year of publication. For each fossil we provide information regarding four features: 1) collection data and depository of the specimen; 2) published illustrations of the specimen; 3) description of the matrix (amber, etc.) and condition of the specimen within the matrix; and 4) comments on the morphology and putative identification of the specimen.

\section{Results}

\section{Fossils most likely belonging to Tortricidae}

\section{Tortricidrosis inclusa Skalski, 1973}

Excavation locality and depository: MNHU Berlin (Holotype: MB L-10=LEP.SUCC.133/AWS)/ Baltic Region (Baltic Amber, Prussian Fm.)/Lutetian, Middle Eocene. The amber collection of C. and H.W. Hoffeins includes a male tortricid moth in Baltic Amber (nr. 1649/3 coll. C. \& H.W. Hoffeins (Hamburg) Baltic Region (Baltic Amber, Prussian Fm.)/Lutetian, Middle Eocene) that WM suspects is conspecific with the holotype of T. inclusa. He simultaneously compared the two specimens under a dissecting scope at MNHU and could find no differences, except in forewing length, which is slightly larger in the specimen from the Hoffeins collection. Based on their morphological similarity and their comparable age, it is possible, that the two fossils are conspecific (Figs $1 \mathrm{a}-\mathrm{f}$.). In the absence of morphological characters to separate or diagnose the two, we treat them as conspecific.

Published illustrations of holotype: Skalski 1973: 339, figs 1-5 (photographs and drawings). 
Condition: The holotype is in a rectangular block $(10 \times 17 \times 4 \mathrm{~mm})$ of amber attached to a microscope slide. It is an adult male moth, forewing length $5.1 \mathrm{~mm}$. The head, thorax and part of the wings are partly covered in a white substance that makes observation of details difficult. The wings are partly folded, and the veins are only partly visible. The fossil moth has retained some of its wing pattern, which is rare in fossils of Lepidoptera.

The specimen in the C. \& H.W. Hoffeins collection is much better preserved than the holotype and reveals several characters that are unobservable in the holotype. It is also a male, and the right wings are perfectly spread, showing a fairly complete forewing pattern (Fig. 1a).
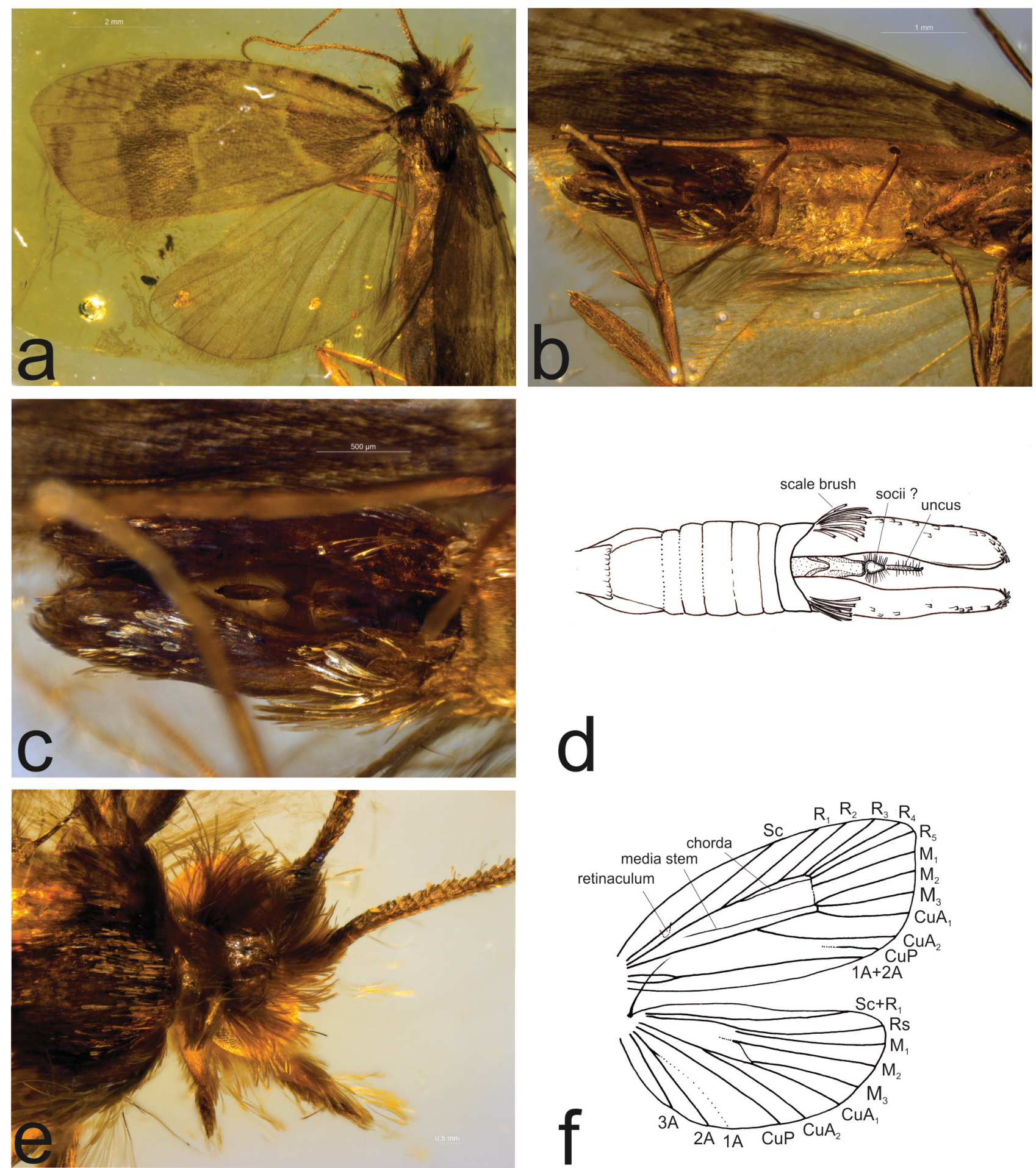

d

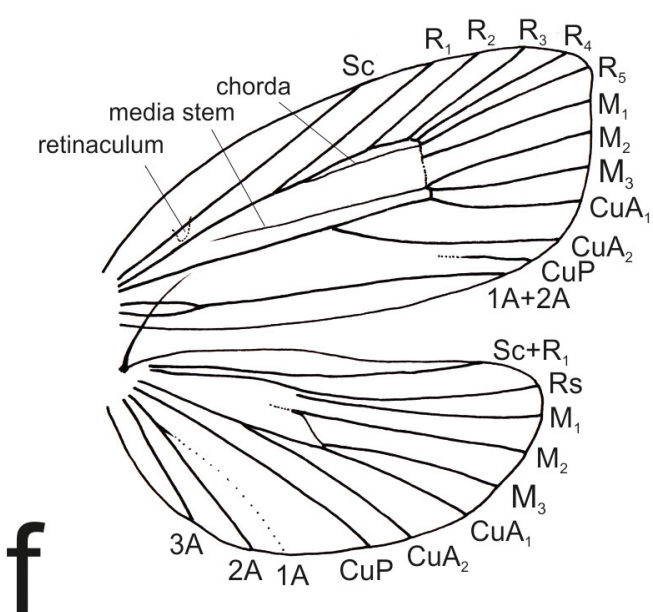

FIGURE 1. Moth in Baltic amber conspecific with Tortricidrosis inclusa Skalski, 1973. Collection of C. and H. W. Hoffeins (Hamburg), nr. 1649/3. a. Dorsal view. Length of forewing $7.8 \mathrm{~mm}$. b. Ventral view of abdomen. c. and d. Male genitalia. e. Head. f. Wing venation. Photos and illustrations: Wolfram Mey. 
Comments: Skalski (1973) presented an illustration of the forewing pattern of the holotype, which includes a basal spot, a median fascia, and a subapical spot, which are found in many species of Tortricidae. He also provided a reconstruction of the venation and descriptions of other visible details.

Based on the second specimen, the following characters can be added to the description of T. inclusa: antenna with short cilia on the ventral side, dorsal side of all flagellomeres with two rows of short scales; ocelli absent; maxillary palpus 3-segmented; haustellum base devoid of scales, short blunt sensilla in the apical portion; tarsal segments with three apical spines ventrally; male genitalia with extremely long valvae, nearly as long as the entire pregenital abdomen, with a long, slender, apically hooked uncus, and short socii.

Skalski (1973) suggested that $T$. inclusa was a member of the extant subfamily Olethreutinae based on the presence of infracellular veins [= the chorda and M stem], "the tendency to straighten the median and cubital veins," and $M_{2}$ and $M_{3}$ straight, with their bases widely separate in the hind wing. The last character is typical of many tortricids and probably represents the plesiomorphic condition in the family. $\mathrm{M}$ stem and stem of $\mathrm{R}_{4+5}$ also are present in some Tortricinae such as Cerace Walker, 1863 (Ceracini; from Eastern Palaearctic), Anacrusis Zeller, 1877 (Atteriini; South and Central American) and in some species of the Australian Arotrophora group (Horak 1984).

Importantly, the flagellomeres of the antennae have two conspicuous rows of scales on the dorsal side. This newly discovered character excludes T. inclusa from Olethreutinae, which have a single row of scales on flagellomeres (Horak \& Brown 1991). The form of the labial palpi, the wing venation, the presence of abdominal scale brushes and the extraordinarily long valvae in the male genitalia suggest that Tortricidrosis should be placed in Chlidanotinae rather than in Tortricinae. Among tortricids in general, many Polyorthini are characterized by extremely long valvae. However, the absence of ocelli is somewhat problematic. Most Chlidanotini and Hilarographini have large ocelli, as do most Polyorthini; ocelli are reduced in a few members of the latter (e.g. Ebodina Diakonoff, 1968), but they also are reduced or obsolete in most Schoenotenini (Tortricinae) (Horak 1998) and in Amorbia Clemens, 1860 (Phillips-Rodriguez \& Powell 2007). The chorda is less troublesome as it is present or absent in Chlidanotini (Brown 1990; Horak 1998). The somewhat "shaggy" scaling of the head is also troublesome, more similar to that of Tineidae than to Tortricidae.

The monophyly of Chlidanotinae has been challenged, and two recent studies based on molecular data suggest that the subfamily is paraphyletic (Regier et al. 2012; Fagua et al. 2017). Although the subfamily of this fossil cannot be determined for certain, we conclude that it most likely is a tortricid.

\section{Tortricites skalskii Kozlov, 1988}

Excavation locality and depository: The specimen was described from the PIRAS, Moscow, but in a recent search was not found in the PIRAS collection (Prof. A. Rasnitsyn, pers. comm.). Holotype: PIN 964/659; PT: PIN 964/660)/Baltic Region (Baltic Amber, Prussian Fm.)/Lutetian, Middle Eocene. The re-assessment is based on the information and illustrations in Kozlov (1988) [original description in Russian].

Published illustrations: Kozlov 1988: 38, fig. 9 (drawing).

Condition: The fossil (holotype) is in two fragments. Adult moth with head, partial body and wings. The forewing length is $6 \mathrm{~mm}$.

Comments: A drawing of the holotype is presented by Kozlov (1988), but some of the information given in the description comes from a fragment of the holotype not included in the drawing. Labial palpi are said to be short and tightly pressed to the head. The long haustellum is coiled into a spiral. The antennae extend beyond the middle of the forewings. The venation in the forewing and hindwing is complete and veins are separate beyond the discal cell. In the forewing, the vein that defines the distal end of the cell is rather narrow; and the bases of $\mathrm{M}_{2}, \mathrm{M}_{3}$, and $\mathrm{CuA}_{1}$ are very close together. In the hindwings, Sc ends near the apex of the wing, and R extends to the apex; $\mathrm{M}_{3}$ and $\mathrm{CuA}_{1}$ are close together at the base.

Based on the characters that can be observed, in particular the wing venation, the fossil most likely belongs to Tortricidae. The tribal assignment to Grapholitini (formerly Laspeyresiini) is also possible based on the short labial palpi appressed to the face, which are found in very few other tortricids. 
Excavation locality and depository: Skalski (1992) reported the FMNH Chicago as the depository of this fossil (Holotype: LEP.SUCC.49 NHMC/AWS/ Baltic Region (Baltic Amber, Prussian Fm.)/Lutetian, Middle Eocene). However, it was not found in the inventory by the FMNH entomology collection manager Crystal Maier and MH. The re-assessment is based on information in Skalski (1992).

Published illustrations: Skalski 1992: 140, figs 1-5 (photographs and drawings).

Condition: According to Skalski (1992), this amber fossil is $10 \times 13 \times 3 \mathrm{~mm}$ and mounted on a microscope slide. It is a male moth with the head, thorax (with legs), one pair of wings and the abdomen preserved. The forewing length is $5.0 \mathrm{~mm}$.

Comments: Tortricibaltia diakonoffi was first mentioned in Skalski (1976) without a description; hence, it was originally a nomen nudum. Skalski (1992) subsequently validated the taxon with a description. The wing venation is typical of Tortricidae, and the genitalia have a slender uncus and elongate valvae, consistent with its assignment to Tortricidae.

By mistake, Tortricibaltia diakonoffi was placed under Olethreutinae in Sohn et al. (2012) (Prof. J.-C. Sohn, pers. comm.). Subsequently, in the divergence time analysis by Fagua et al. (2017) this fossil was used to give a minimum age to Olethreutinae. To support this placement, Fagua et al. (2017) mention "the presence of forewing veins M-stem and stem of R4+5". Although these authors acknowledge that this is a plesiomorphic trait among extant Tortricidae, they mention that it is found almost exclusively in Olethreutinae. However, in the absence of other characters, we consider the evidence weak. In addition, the presence of a well developed CuP is somewhat troublesome. According to Horak (2006: 25), in Olethreutinae the cubitus posterior (CuP) is present with very few exceptions near the wing margin but never as a fully developed vein. In its reduced form, it is usually present, although it is absent altogether in Cochylini (Horak 1998: 199). Because the reported characters of the fossil do not include apomorphies or character combinations that would unambiguously place it reliably in any of the tortricid subfamilies or tribes, we find its use it as a calibration point to give a minimum age to Olethreutinae unfounded. Regardless of its tribal and/or subfamilial assignment, this fossil appears to be a tortricid.

\section{Polyvena horatis Poinar \& Brown, 1993}

Excavation locality and depository: George Poinar, Jr. private collection (Holotype: L-3-24)/ Dominican Republic: Cordillera Septentrional between Santiago and Puerto Plata, La Toca group of mines (Dominican Amber, La Toca Fm.)/Burdigalian, Early Miocene. The fossil was examined by JWB.

Published illustrations: Poinar and Brown 1993: 26, 28, figs 1-3.

Condition: The amber piece is roughly elliptical in shape $(27 \times 16 \times 4 \mathrm{~mm})$. The fossil is an adult male with a forewing length of $5.8 \mathrm{~mm}$. The specimen is entirely intact with most of the mouthparts and legs visible, and it is exceptional in that the wings are spread allowing the examination of the venation and showing a hint of raised scales. The elongate external portion of the valvae of the genitalia can also be observed.

Comments: Poinar and Brown (1993) provide a detailed description and illustrations of the moth. The authors place the fossil with certainty in the extant subfamily Chlidanotinae based on the presence of the following characters: a generalized wing venation with hindwing veins $\mathrm{M}_{2}$ and $\mathrm{M}_{3}$ widely distant, raised scale tufts on the forewing, and elongate valvae. Unfortunately, the most compelling morphological character that supports the monophyly of the subfamily is the presence of a deep longitudinal invagination on the male valva holding a hairpencil arising from the eighth abdominal segment (Horak \& Brown 1991), which is not visible on the fossil moth.

In the molecular phylogeny of Tortricidae by Regier et al. (2012), Chlidanotinae was not recovered as monophyletic, and a paraphyletic Chlidanotinae was chosen as the working hypothesis. Regier et al. (2012) confirmed that Chlidanotinae (as monophyletic or paraphyletic) are the most basal tortricid lineage and recognized the division of the subfamily into three tribes: Polyorthini plus a monophyletic Hilarographini + Chlidanotini, with Polyorthini as the first lineage to diverge. Fagua et al. (2017) also recovered a paraphyletic Chlidanotinae as the basal-most lineages of Tortricidae.

Poinar and Brown (1993) exclude the moth from Chlidanotini and Hilarographini because of differences in the 
morphology diagnostic of these tribes (e.g., members of these tribes lack raised scales of the forewing and most have conspicuously thickened antennae). Characters indicating that the moth likely belongs to Polyorthini include the termination of vein $\mathrm{R}_{5}$ before the apex of the wing found in many Polyorthini; the presence of raised scales on the forewing, and the presence of elongate valvae in the male genitalia. However, the authors consider the assignment of the fossil specimen to this tribe tentative because the most convincing synapomorphies of the tribe are in the male genitalia, which are not visible in the fossil specimen. Nonetheless, we consider this specimen to be a member of Tortricidae.

Polyvena horatis was used by Fagua et al. (2017) to give a minimum age to Chlidanotinae. This use of the fossil is problematic because, as noted above, the subfamily is not monophyletic. Fagua et al. (2017) chose to place the calibration point at the crown of Polyorthini following the suggestion by Poinar and Brown (1993) that the moth could belong in this tribe.

Currently, Polyvena horatis is one of the most thoroughly described fossil tortricids. Although the specimen does not display the full suite of characters characteristic of Chlidanotinae or Polyorthini, the visible characters are in favor of this placement.

\section{Antiquatortia histuroides Brown \& Baixeras, gen. nov., sp. nov.}

Figs 2 a-d.

Collection data and depository: AMNH, New York (Holotype: DR8-43)/Dominican Republic: Cordillera Septentrional between Santiago and Puerto Plata, La Toca group of mines (Dominican Amber, La Toca Fm.)/ Burdigalian, Early Miocene. The specimen was borrowed and examined at the USNM.

Published illustrations: Grimaldi \& Engel 2005: 580, fig. 13: 47 (photograph).

Condition: The piece of amber is elliptical in shape $(45 \times 23 \times 7 \mathrm{~mm})$. The fossil is a female moth with an intact head (although the right antenna is broken) with most of the mouthparts visible, and the left hind wing is nicely spread allowing the examination of both the fore- and hindwing venation. A mite is attached to its left compound eye.

\section{Antiquatortia Brown \& Baixeras, gen. nov.}

Type species: Antiquatortia histuroides Brown \& Baixeras, sp. nov.

Description. Head: Vertex rough-scaled, frons with narrow scales. Antenna slender, slightly serrate, ca 0.4 times length of forewing, lacking conspicuous sensory setae, with two rows of scales per flagellomere. Ocelli present. Chaetosemata not visible. Labial palpus long, porrect; second segment ca 4.0 times length of first and third segment, expanded medially on dorsal side, third segment slender, rod-like, slightly tapering apically. Maxillary palpus not visible. Haustellum well developed, coiled, unscaled at base, with stout sensilla on distal half.

Thorax: Foreleg tibia with epiphysis; mid- and hindtibia with two pairs of spurs, the more medial spur longer; tarsus with apical spines on ventral side. Forewing discal cell length about 0.6 forewing length; all veins $\left(\mathrm{Sc}, \mathrm{R}_{1}-\mathrm{R}_{5}\right.$, $\mathrm{M}_{1}-\mathrm{M}_{3}, \mathrm{CuA}_{1}-\mathrm{CuA}_{2}$ and $1 \mathrm{~A}+2 \mathrm{~A}$ ) present and separate, $\mathrm{R}_{5}$ extending to costa; neither chorda nor $\mathrm{M}$-stem evident. Patches of upraised scales on the forewing. Hindwing with costa slightly sinuate, with a concave region preapically (Figs $2 \mathrm{a}-\mathrm{b}$ ); $\mathrm{Sc}+\mathrm{R}_{1}$ and Rs approximate at base, $\mathrm{M}_{2}$ and $\mathrm{M}_{3}$ apparently parallel; $\mathrm{M}_{3}$ and $\mathrm{CuA}_{1}$ stalked; frenulum with three acanthi.

Abdomen: Female genitalia with papillae anales weak, but apparently flat.

Diagnosis. In wing venation Antiquatortia is similar to Polyvena, but in Polyvena the chorda and the M-stem are present, whereas both are absent in Antiquatortia. Both specimens possess patches of what appear to be upraised scales on the forewing, a feature characteristic of both sexes of Polyorthini and Tortricini, although occurring sporadically elsewhere in Tortricidae (Horak 1998). Because the forewing pattern is obscured in both fossils, no comparison of pattern can be made. In addition, because Polyvena is a male and Antiquatortia a female, no comparisons regarding other external features are particularly relevant (i.e., number of acanthi in the frenulum, male secondary features, etc.) 
Etymology. The genus name is a Latinized derivative name freely inspired in the contraction of the Latin word "antiqua" (meaning old, ancient) and the type genus of the family Tortricidae "Tortrix". It is feminine in gender.
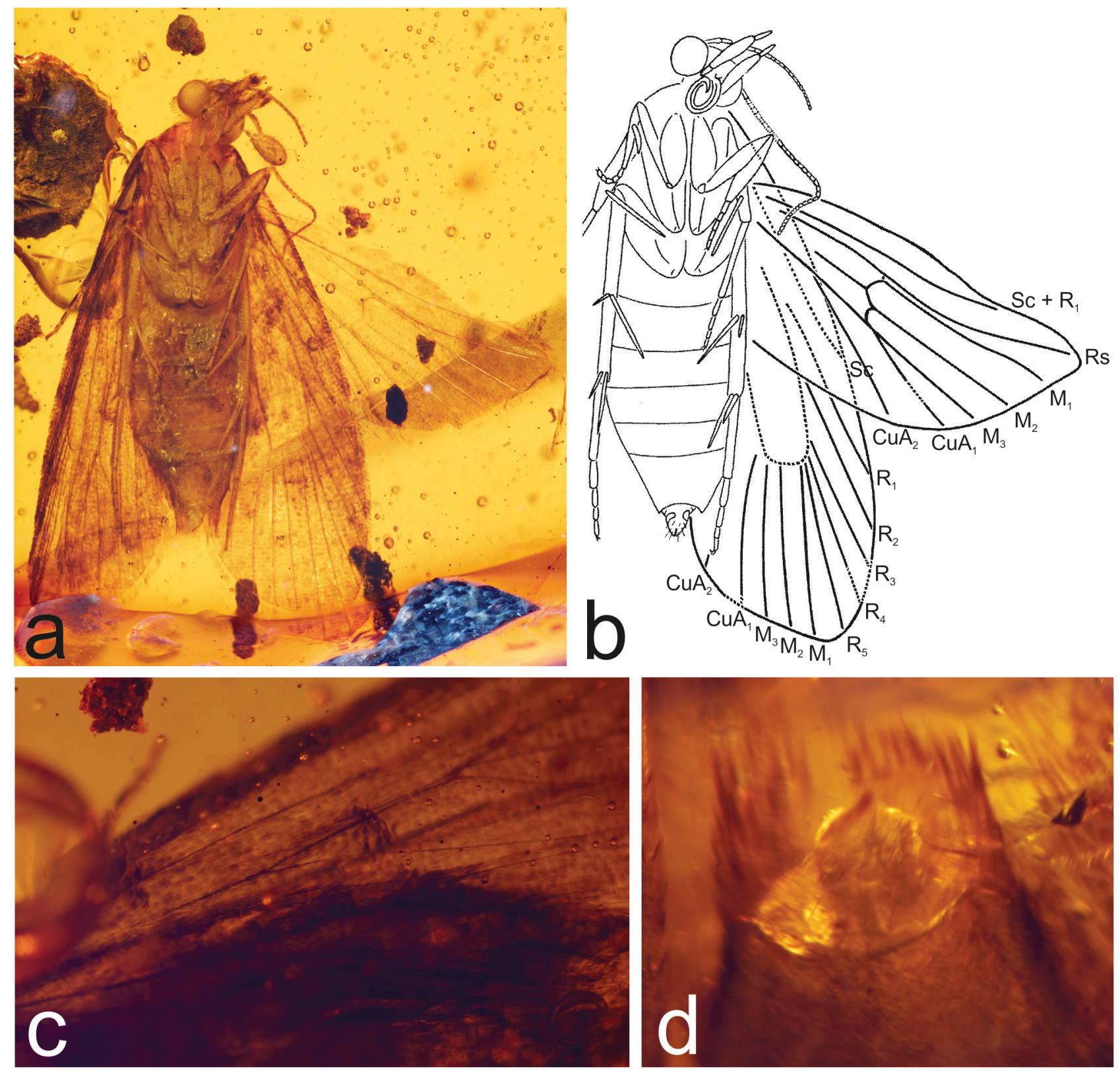

FIGURE 2. Antiquatortia histuroides Brown \& Baixeras, gen. nov., sp. nov. AMNH DR8-43. Dominican amber. a. Ventral view. Length of forewing $7 \mathrm{~mm}$. b. Wing venation c. Dorsal view of forewing with tufts of erect scales. d. Papillae anales. Photos: Mark Metz. Illustration: Joaquin Baixeras.

\section{Antiquatortia histuroides sp. nov.}

Description. Female. Forewing length $7 \mathrm{~mm}$. Head as described above for the genus.

Thorax: Dorsum with appressed scaling, presumably brown. Ventral side lighter in color. No trace of forewing pattern; traces of two patches of raised scales in identical positions on both forewings: one below the discal cell between the bases of $\mathrm{M}_{3}$ and $\mathrm{CuA}_{1}$, the other inside discal cell at base; some ill-defined intervenular patches of scales at costal level suggest the presence of a developed strigulae system.

Abdomen: Tergites covered by wings. Sternites with appressed scales concolorous with thorax.

Diagnosis. Antiquatortia histuroides is superficially similar to Polyvena horatis but is clearly discriminated by the generic-level characters discussed above in the generic diagnosis. 
Etymology. The specific name is a feminine singular adjective based on the genus name Histura Razowski, a diverse genus of Polyorthini in Central America, with the suffix "-oides", meaning "similar to".

Type material: Holotype AMNH DR8-43 deposited at the AMNH, New York. U.S.A.

Comments: The presence of ocelli and a frenulum with three acanthi are all typical female characters in Tortricinae and Polyorthini (Chlidanotinae); in females of Chlidanotini and Hilarographini, the two other tribes of Chlidanotinae, the frenulum usually has only two acanthi (Yang \& Brown 2009). The chaetosemata, which are highly characteristic of Tortricidae and lacking in similar microlepidoptera, are not visible. Two rows of scales and extremely short sensory setae of the antenna are key features of Tortricinae (Horak \& Brown 1991). The forewing venation is characteristic of many Archipini and Polyorthini, and the hindwing venation does not contradict this assignment. The slightly sinuate costa of the hindwing with a concave region preapically (Figs $2 \mathrm{a}-\mathrm{b}$ ) is a feature that is found in many Archipini, a few Sparganothini (e.g., Amorbia Clemens, 1860), and many Eucosmini. The patches of raised scales are typical of Tortricini and Polyorthini, although present in a few genera scattered throughout the family (Fig. 2 c). The papillae anales are weak, but they appear to be flat as in most tortricids (Fig. 2 d). There is nothing that contradicts the assignment of this specimen to Tortricidae. This combination of characters, especially the raised forewing scales and somewhat elongate labial palpi, suggest that the specimen represents Polyorthini, and we provisionally assign it to that tribe. This assignment must be considered tentative because the most convincing synapomorphies of the tribe are in the genitalia and not visible in this fossil specimen.

\section{Electresia zalesskii Kusnezov, 1941}

Figs 3 a-c.

Excavation locality and depository: Formerly, the fossil was in the private collection of B. V. Miloradovitsch, Russia, but it is currently in the collection of the PIRAS Moscow (Holotype: no. 20). In the original description the inclusion is reported to be in Baltic amber (Baltic Region, Prussian Fm./Lutetian, Middle Eocene), but Prof. A. Rasnitsyn has examined the specimen and concluded it is copal (pers. comm.). The surface of this specimen, as that of the fossil pyraloid Glendotricha olgae Kusnezov, 1941, show greater deterioration than the other amber specimens dealt with in the same paper by Kusnezov (1941) and deposited at the PIRAS. In addition, solubility tests were conducted on small, detached pieces of Glendotricha olgae. In less than an hour in $95 \%$ alcohol, these particles turned into an opaque jelly-like mass, a reaction typical to copal but which never occurs when alcohol is applied to real Baltic amber (a succinite). Copal is younger than amber (Poinar 1992; Labandeira 2014), but a more precise age and origin of Electresia zalesskii are currently not known. The re-assessment of the fossil moth is based on the information and illustrations found in the original publication by Kusnezov (1941) and the examination of the specimen at the PIRAS (MH).

Published illustrations: Kusnezov 1941: 63, figs 50-52 (drawings) and reproduction in Carpenter 1992: 374, fig. 2 (drawing).

Condition: The irregularly shaped copal piece $(21 \times 23 \times 8 \mathrm{~mm})$ shows signs of physical degradation. The surface has a dense network of small cracks making it very difficult to examine the moth (forewing length $4.2 \mathrm{~mm}$ ) within it (Fig. 3). The sex of the moth cannot be determined with certainty, but based on the absence of sensory setae on the flagellomeres of the antenna, it is likely a female. The wings are folded roof-like over the abdomen, so only the forewing venation can be observed; the legs are partly visible.

Comments: Kusnezov (1941) assigned this fossil to "Eucosmidae" (now considered a tribe of Olethreutinae), indicating that it is closely allied to the genus Laspeyresia Hübner, 1825 (now Cydia in the tribe Grapholitini). This placement was based on a variety of morphological characteristics, including the following: length of the antennae (slightly longer than half the forewing length); configuration of the labial palpi (a short basal segment, a longer second segment, and a short, obtuse third segment); the absence of (or inconspicuous) maxillary palpi; the overall forewing shape (trapezoidal, 2.5 times long as wide, with apex rounded and obtuse, and termen slightly incurved at $\mathrm{M}_{1}$ ) and venation (all veins present and separate beyond the discal cell, with well-developed chorda and $\mathrm{M}$ stem). The chaetosemata are not mentioned, and cannot be observed in this fossil. The scaling of the antennae is difficult to see, but it appears that there is only one row of scales. All of these features are highly consistent with the assignment of the specimen to Tortricidae, and the slightly undulate termen in forewings is certainly similar to that of many recent Olethreutinae (e.g. Irianassa Meyrick, 1905, Periphoeba Bradley, 1957). 
The monophyly of Olethreutinae is strongly supported by morphological (e.g. Horak 1998) and molecular data (e.g. Regier et al. 2012; Fagua et al. 2017). Horak (1998) stated that Olethreutinae differ from Tortricinae in the retention of the M-stem and the chorda in the forewing discal cell, but these plesiomorphic features are also present in some Chlidanotinae (Polyorthini and Hilarographini). Regardless of its tribal and/or subfamilial assignment, we conclude that this fossil belongs to Tortricidae.
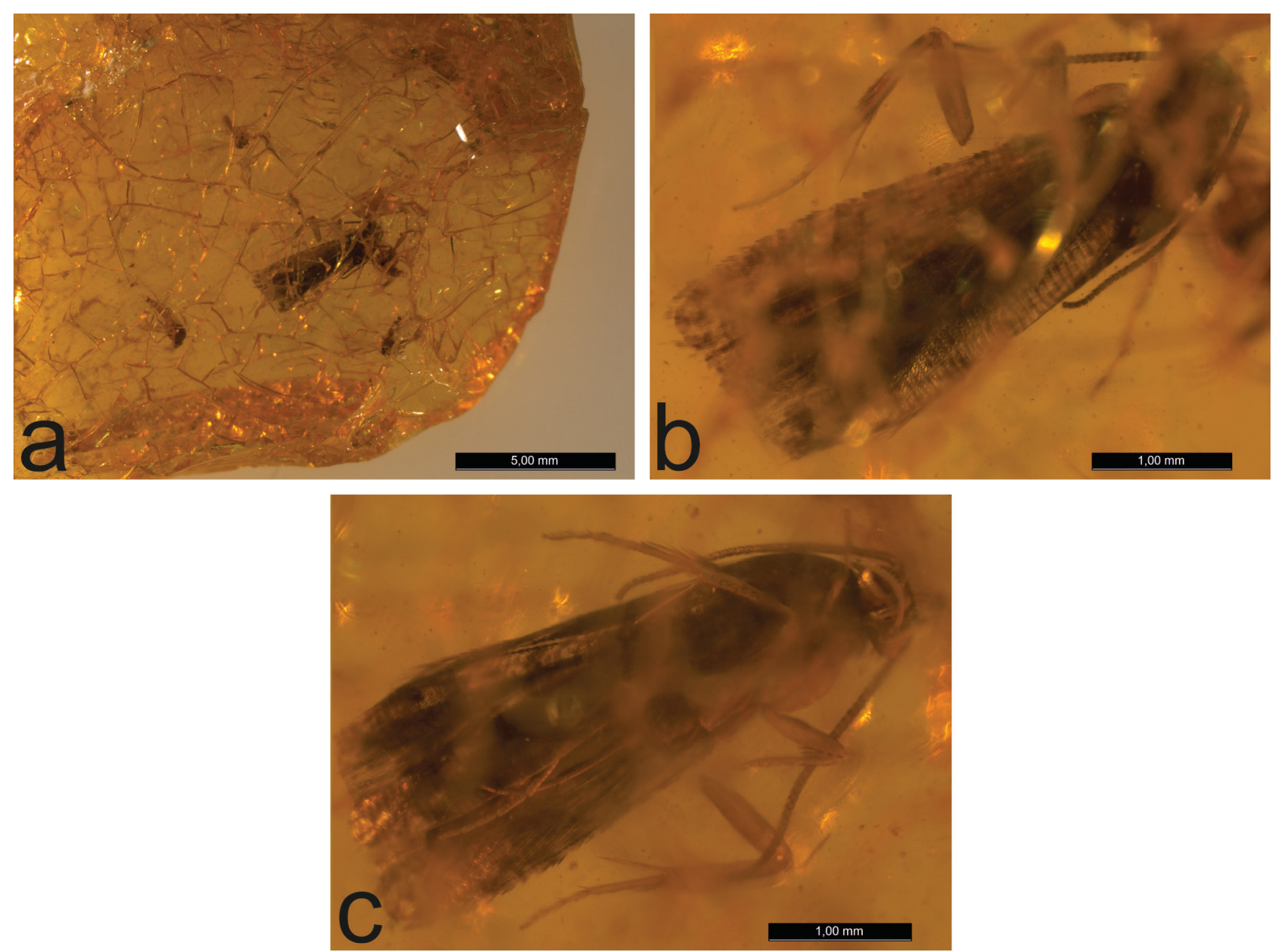

FIGURE 3. Electresia zalesskii Kusnezov, 1941. PIRAS (HT: no. 20). a. Crazing on the surface of the copal piece. b. Dorsal view. Length of forewing $4.2 \mathrm{~mm}$. c. Ventral view. Photos: Maria Heikkilä.

\section{Trace fossil}

[larval feeding damage of $c f$. Retinia resinella (Linnaeus, 1758) on Pinus L. sp. (Pinaceae) stem]

Excavation locality and depository: Peat deposit and trace fossil; MZH Helsinki (1 ex: 1000J, R 16)/Finland: Umgebung, Piilonsuo Moors (peat deposits)/Pleistocene.

Published illustrations: Koponen \& Nuorteva 1973: 60, fig. 24 (black and white photograph).

Condition: The pine stem shows a scar suspected to be larval feeding damage caused by the pine resin-gall moth Retinia resinella (Linnaeus, 1758).

Comments: Koponen and Nuorteva (1973) attributed the larval feeding damage to Retinia resinella. The larva of this species causes a resin-gall in second year pine trees. The larva feeding under the gall makes a cut in the stem reaching all the way to the heartwood. In slow-growing and dying pine trees, these cuts do not close but are left as open scars. Resin-galls are frequently found on pines growing in marshy areas (Saalas 1949; Koponen \& Nuorteva 1973). The gall persists on the stem for years after the larva has left. The abandoned galls are often inhabited by other species, such as Cydia cosmophorana (Treitschke, 1835) (Tortricidae), certain cecidomyids (Diptera) and 
chalcidoids (Hymenoptera), which bore into the gall, feeding on it from the inside. When pressure is applied to such brittle galls, they fall off easily leaving no trace of the resin gall, and the scar under it is left exposed (Dr. L. Kaila, pers. comm.).

The trace fossil does not show any remains of the resin gall, but the scar is typical of Retinia resinella. The only other species to produce similar resin galls, $R$. perangustana (Snellen, 1883), feeds on larch (Larix Philip Miller, Pinaceae) (Dr. L. Kaila, pers. comm.). We conclude that the feeding damage on the stem may have been caused by $R$. resinella.

\section{Fossils most likely not belonging to Tortricidae or character evidence is too meagre}

\section{Spatalistiforma submerga Skalski, 1992}

Figs $4 \mathrm{a}-\mathrm{b}$.

Excavation locality and depository: ZMCD Copenhagen (Holotype: 12-4/1957=LEP.SUCC.88 UZMC/AWS) / Baltic Region (Baltic Amber, Prussian Fm.)/Lutetian, Middle Eocene. The specimen was borrowed and examined at the USNM by JWB, MH and Richard L. Brown.

Published illustrations: Skalski 1992: 142, fig. 6 (photographs and drawings).

Condition: The moth is in a $7 \times 9 \times 4 \mathrm{~mm}$ piece of Baltic amber. The head, abdomen and legs are missing; only the thorax and the wings have been preserved. Forewing length is $3 \mathrm{~mm}$. The presence of a single acanthus in the frenulum suggests the moth is a male and belongs to Heteroneura.

Comments: The first mention of Spatalistiforma submerga by Skalski (1976) must be considered a nomen nudum since it lacks a description. However, Skalski (1992) subsequently validated the name by providing a description. Skalski (1992) tentatively placed the fossil moth in the tribe Tortricini based on purported similarities in the wing venation with the genus Spatalistis Meyrick, 1907. According to Skalski, among recent Tortricidae, only Spatalistis has $\mathrm{M}_{3}$ and $\mathrm{CuA}_{1}$ veins stalked in both the fore and hindwing. However, Skalski acknowledged that the wing shape and at least two venational features of Spatalistiforma are different from those found in Spatalistis and allied genera.

There are no characters that convincingly assign the specimen to Tortricidae, and there are subtle features that suggest it is not a tortricid. The overall shapes of both the forewing and hindwing are not particularly characteristic of Tortricidae. In the forewing the termen is strongly angled inward, giving it an appearance that is more tineoid than tortricoid. In most tortricids, especially Tortricini (and most other Tortricinae), the termen is oblique or slightly angled inward, giving the forewing a much more triangular appearance. Plus, the forewing pattern (which appears to be somewhat intact) is reminiscent of a tineid and not a tortricid. The unusual, long, slender scales from the costa of the forewing are present in no known tortricids, but we know of no other family with such forewing scales. The hindwing, likewise, has a shape that is more typical of Tineoidea and/or Yponomeutoidea (e.g. Plutellidae, Yponomeutidae), somewhat broadly lanceolate-rounded. In Fig. $4 \mathrm{~b}$ the vague presence on the hindwing of a darker patch reminiscent of male secondary scales found in many tortricids is actually a detached leg with a tibial spur. Overall, the specimen bears little resemblance to Spatalistis, which has a strongly oblique forewing termen and raised scales on the forewing.

This fossil was used as a calibration point in the divergence time study by Fagua et al. (2017) to give a minimum age to Tortricinae. Based on the reasons given above, we find the original interpretation of the fossil as a tortricid unwarranted and its use as a calibration point for the purpose intended incorrect.

\section{Unnamed adult fossil moth tentatively assigned to Olethreutinae by Skalski (1992)}

Excavation locality and depository: Skalski (1992) reported the FMNH Chicago as the depository of this fossil (1 ex: LEP.SUCC.35 NHMC/AWS/ Baltic Region (Baltic Amber, Prussian Fm.)/Lutetian, Middle Eocene). However, it was not found in the inventory by the FMNH entomology collection manager Crystal Maier and MH. The reassessment is based on information in Skalski (1992).

Published illustrations: Skalski 1992: 145, fig. 7 (photograph and drawing). 
Condition: Skalski (1992) described the specimen as a $10 \times 15 \times 3 \mathrm{~mm}$ piece of amber mounted on a microscope slide. Adult moth with only the head, basal part of the forewings, and one midleg preserved and visible.

Comments: Skalski described the species under the headings "Incertae Sedis" and "Gen.? spec.?", a clear indication of the lack of characters for a confident description of the fossil. Although it is possible that the fossil is a Tortricidae, this assessment is based entirely on the shape of the labial palpi alone (and the absence of contradictory characters), rather than a combination of characters. Hence, we consider that the evidence is too meager to support the confident placement of the fossil in Tortricidae.
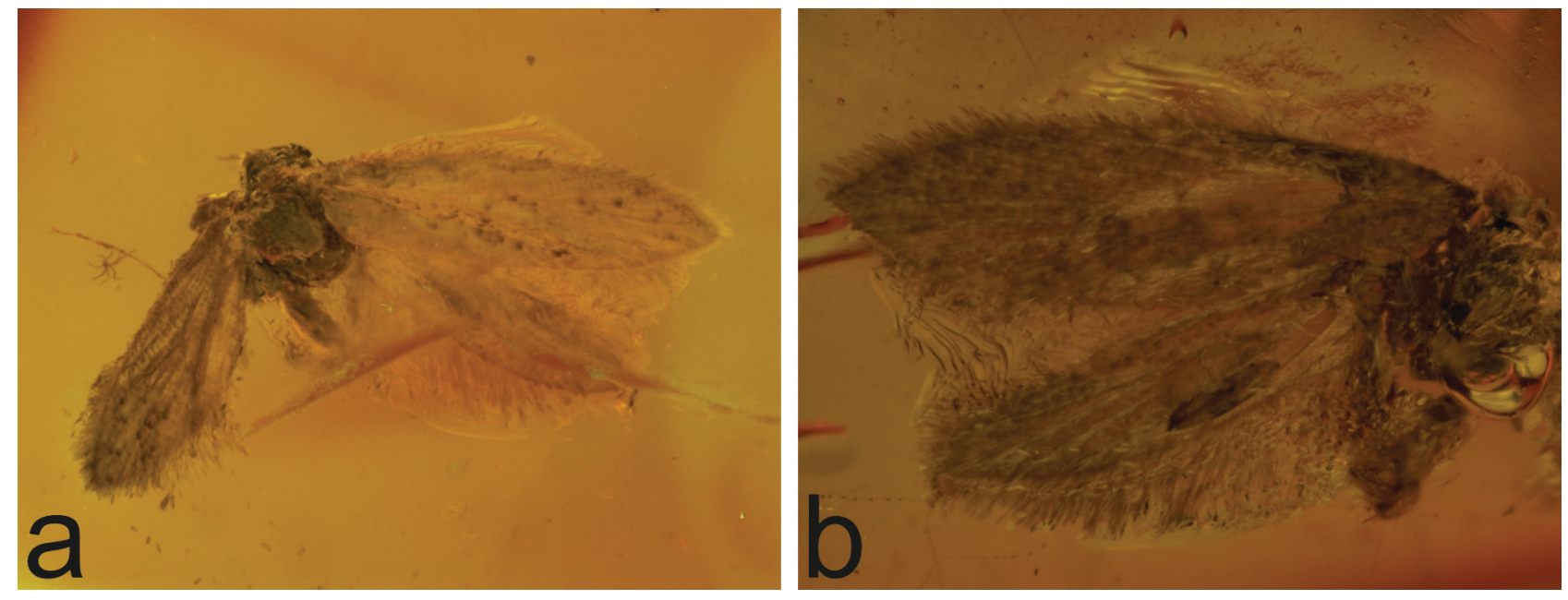

FIGURE 4. Spatalistiforma submerga Skalski, 1992. ZMCD (HT: 12-4/1957=LEP.SUCC.88 UZMC/AWS). Baltic amber. a. Dorsal view. Length of forewing $3 \mathrm{~mm}$. b. Ventral view. For details of venation see Skalski (1992). Photos: Maria Heikkilä.

\section{Paleolepidopterites Kozlov, new collective group}

Description. The collective group name Paleolepidopterites is proposed for fossil Lepidoptera that cannot be placed with certainty in any known family. Therefore, the diagnosis of this collective group is identical to the diagnosis of the order Lepidoptera (published e.g. by Kozlov et al. 2002).

Etymology: from $\pi \alpha \lambda \alpha i o ́ \varsigma$ (palaios), Ancient Greek = old; $\lambda \varepsilon \pi i \zeta$ (lepis), Ancient Greek $=$ scale; $\pi \tau \varepsilon \rho o v$ (pteron), Ancient Greek = wing.

Comments. Collective group names ending with '-ites' are commonly used for fossil insect species, especially Lepidoptera, whose taxonomic placement is not entirely convincing or for which only family-level association is assured (Sohn et al. 2012; Sohn \& Lamas 2013). Such names are valid according to the code (ICZN 4th edition, Articles 20, 23.7 and 42.2.1) and are subject to the rules for genus-group nomenclature, except that collective groups have no type species. The erection of the new collective group, Paleolepidopterites, is motivated by the impossibility to keep the three following fossils within the collective group Tortricites, because these fossils, most likely, do not belong to the family Tortricidae.

The collective group Tortricites Kozlov, 1988, in accordance with ICZN 4th edition, Article 42.3.1, was described without indicating the type species. Later on, Gilligan et al. (2014) mentioned T. sadilenkoi Kozlov, 1988 as the type species of Tortricites. However, this action is invalid and does not affect the validity of this collective group name, Tortricites, in spite of the transfer of T. sadilenkoi into a new collective group, Paleolepidopterites.

\section{Paleolepidopterites florissantanus (Cockerell, 1907), comb. nov.}

Fig. 5.

[Tortrix florissantanus Cockerell, 1907; generic combination Tortricites florissantanus (Cockerell, 1907) proposed by Sohn et al. 2012].

Excavation locality and depository: UCNH Boulder (Holotype: no. 8579)/USA: Colorado, Teller County, 
Florissant Beds National Monument (Florissant Fm.)/late Priabonian, Late Eocene. The examination of this compression fossil is based on high-quality photographs provided by the UCNH.

Published illustrations: Meyer 2003: 224, fig. 194 (photograph).

Condition: This is a compression fossil of a moth with its wings folded. The size of the piece of stone is $6.4 \times$ $4.5 \mathrm{~cm}$. The length of body including the head is $14 \mathrm{~mm}$. Forewing length is $13 \mathrm{~mm}$. The moth is female based on the presence of three acanthi in the frenulum at the base of the right hindwing (although Cockerell (1907) reported two acanthi). Clear veins or scales cannot be observed in the photograph of this fossil.

Comments: The concave costa of the forewing led Cockerell (1907) to assign the moth to Tortricidae (Tortrix). However, Skalski (1992) considered this family assignment uncertain. We share this opinion as no morphological details are visible to support placement in Tortricidae. Although a concave costa of the forewing occurs in a few tortricids, it is a more widespread feature in other families, e.g. in Pyraloidea and Gelechioidea. Hence, we question the assignment of this fossil to Tortricidae. The acanthi indicate that the moth belongs to Heteroneura, but because the character evidence is extremely meagre, we do not have suggestions regarding a more precise taxonomic placement.

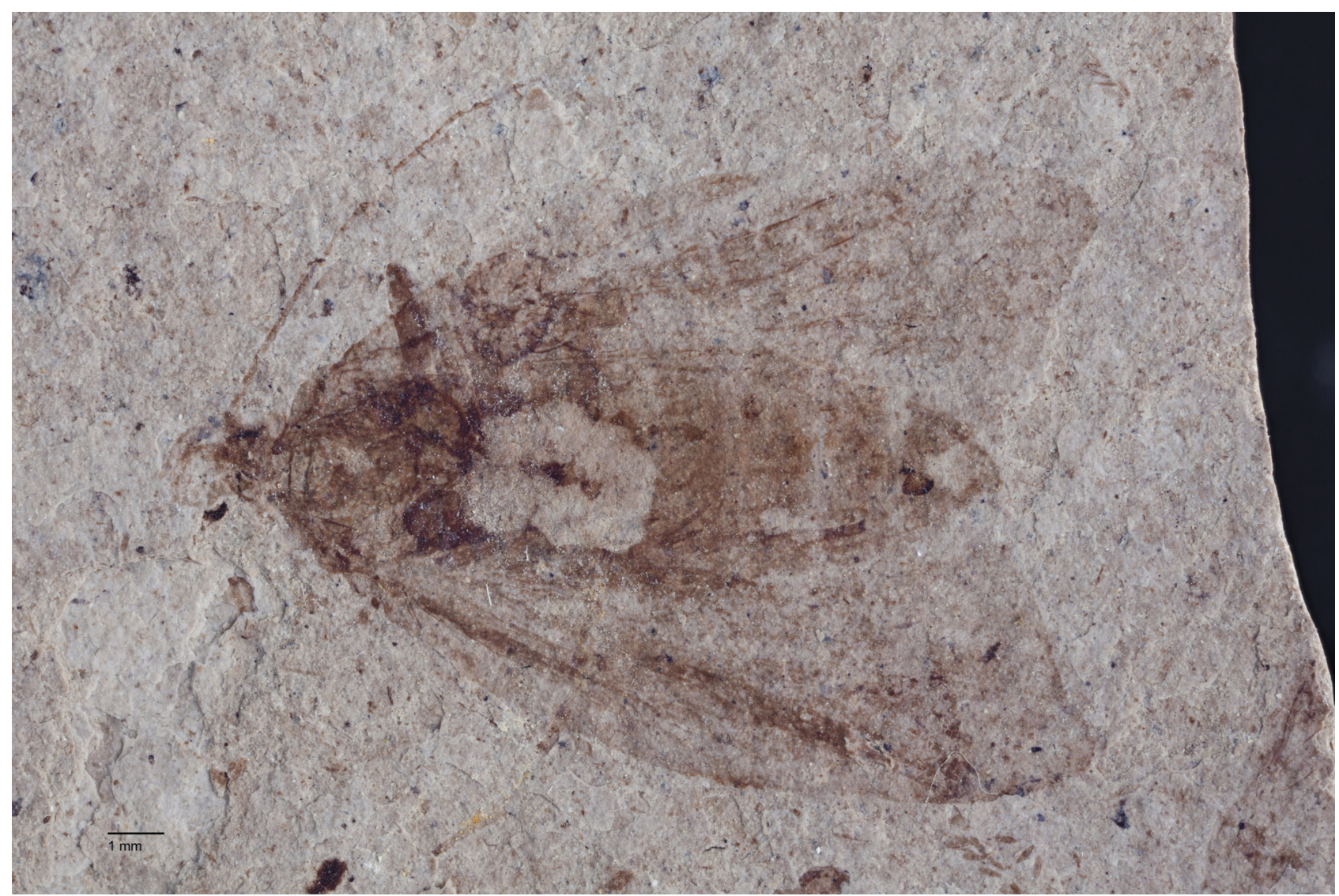

FIGURE 5. Paleolepidopterites florissantanus (Cockerell, 1907), comb. n. UCNH (HT: no. 8579). Compression fossil, Florissant Beds National Monument. Length of body including head $14 \mathrm{~mm}$. Photo: David Zelagin. The image was generated by the Fossil Insect Collaborative TCN.

\section{Paleolepidopterites destructus (Cockerell, 1916), comb. nov.}

Fig. 6.

[Tortrix (?) destructus Cockerell, 1916; generic combination Tortricites destructus (Cockerell, 1916) proposed by Sohn et al. 2012].

Excavation locality and depository: USNM Washington D.C. (Holotype: no. 61998)/USA: Colorado, Teller County, Florissant Beds National Monument (Florissant Fm.)/late Priabonian, Late Eocene. The examination of this compression fossil was done by JWB and MH. 
Published illustrations: none

Condition: This species was described as Tortrix (?) destructus from a compression fossil of an adult moth with a forewing length of about $8.3 \mathrm{~mm}$. The wings are folded. Short fragments of a few veins can be observed. Obvious impressions of scales are not present.

Comments: The compression fossil shows no reliable evidence for placement in Tortricidae. Skalski (1992) also concluded that the familial assignment of this fossil is uncertain. The poor preservation of the fossil and the lack of character evidence do not allow making suggestions about its taxonomic placement, but the general habitus of the insect suggests it is lepidopteran.

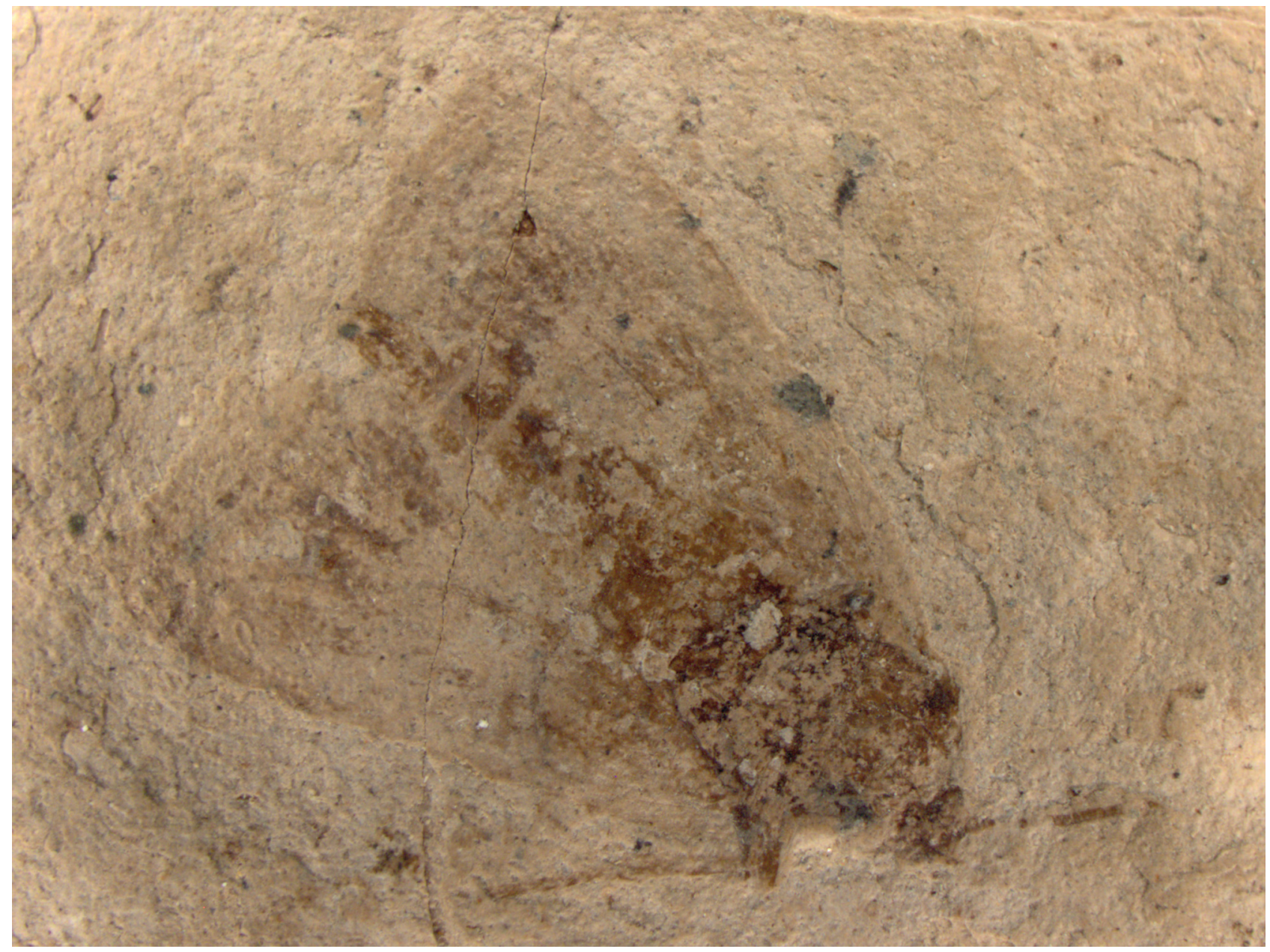

FIGURE 6. Paleolepidopterites destructus (Cockerell, 1916), comb. n. USNM (HT: no. 61998). Compression fossil, Florissant Beds National Monument. Length of forewing $8.3 \mathrm{~mm}$. Photo: Alan Rulis.

Paleolepidopterites sadilenkoi (Kozlov, 1988), comb. nov.

Fig. 7.

[Tortricites sadilenkoi Kozlov, 1988]

Excavation locality and depository: Current location unknown. Formerly, the specimen was in the private collection of K. M. Sadilenko, Moscow, Russia, but was stolen (MVK, pers. comm.)/ (Holotype: no. 4) Baltic Region (Baltic Amber, Prussian Fm.)/Lutetian, Middle Eocene. The re-assessment is based on information in Kozlov (1988) and original notes, drawings and photographs by MVK. Some of the information mentioned below was not included in the primary description.

Published illustrations: Kozlov 1988: 38, fig. 8 (drawing).

Condition: The size of the amber piece: $40 \times 35 \times 15 \mathrm{~mm}$. Amber light, transparent. The piece also contained 
four ants. Adult female moth with head, thorax and partial forewing. Length of forewing $5.3 \mathrm{~mm}$. Measurements not included in original description: body length without head $4.6 \mathrm{~mm}$, length of antenna $2.7 \mathrm{~mm}$, hind femur 1.0 $\mathrm{mm}$, hind tibia $2.3 \mathrm{~mm}$, tarsus $1.8 \mathrm{~mm}$. Forewing venation clearly visible. Hindwing venation almost indistinguishable. Frenulum consists of three acanthi.

Comments: Kozlov (1988) stated that the assignment of the fossil to Tortricidae is doubtful due to the insufficient preservation of the moth. However, he also wrote that within Tortricidae the species should be assigned to the tribe Cochylini. The shape of the papillae anales is not visible in the available drawings and photographs, and it is possible that details of the female genitalia were not observable. The presence/absence of chaetosemata is not mentioned. The shape of the labial palpi is consistent with those of many tortricids and the wing shape and venation are typical of Tortricidae. The presence/absence of $\mathrm{CuP}$ is not observable (absent in most Cochylini). Because the available character evidence is scant and the examination of the actual specimen is not possible, we prefer to follow the assessment of Kozlov (1988) and consider the assignment of the fossil to Tortricidae uncertain. The moth is heteroneuran and based on the size, wing shape and venation, details of the antennae, haustellum, maxillary and labial palpi (see e.g. Davis 1998; Davis \& Gentili 2003), most likely does not belong to extant families of monotrysian Heteroneura.

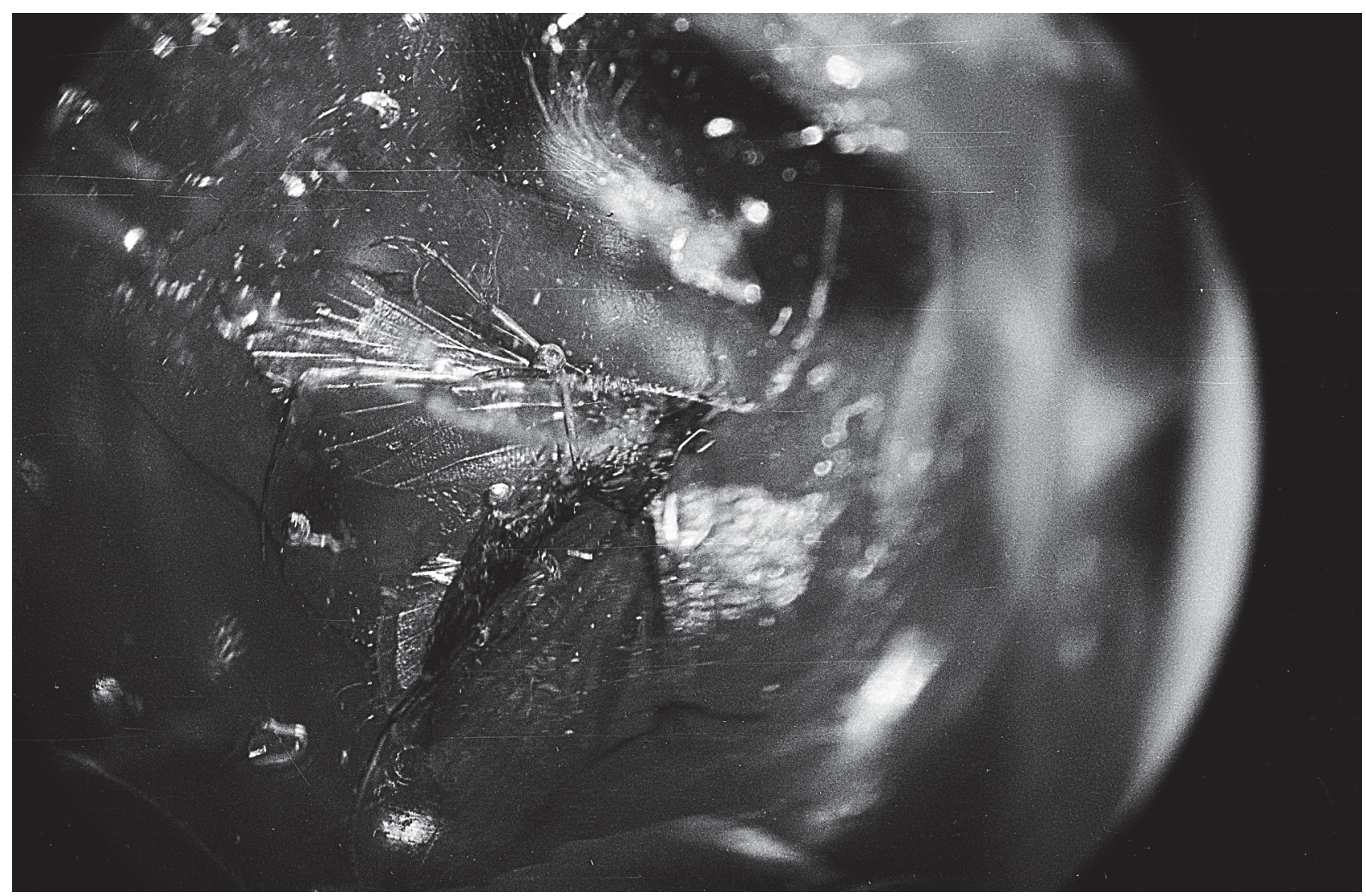

FIGURE 7. Paleolepidopterites sadilenkoi (Kozlov, 1988), comb. n. Baltic amber. Specimen has been stolen from the private collection of K. M. Sadilenko, Moscow, Russia (HT: no. 4). Photo: Mikhail V. Kozlov.

\section{Discussion and conclusions}

Re-examination and identification of fossil Tortricidae. Fossil Tortricidae pose a problem for synapomorphybased assignment to family, subfamily and tribe. Although proposed apomorphies of Tortricidae are few and were observed in only one of the thirteen specimens examined, six specimens possess a combination of characters indicating that they most likely belong to the family Tortricidae. These characters, listed in the Material and Methods section, and the importance of the process of elimination to exclude the fossil moths from other groups of Lepidoptera, provide the best evidence available in the absence of apomorphic characters and without the 
possibility of examination of the genitalia. None of the characters utilized are unique to Tortricidae, but when found in combination, they provide fairly compelling evidence for assignment of the specimens to this family.

External characters that would enable placing a fossil tortricid in a subfamily or tribe are also rare, and the placement to lower taxonomic levels also require examining the genitalia. Genitalia are rarely clearly visible in fossils, and time-consuming and expensive $\mu \mathrm{CT}$-scanning would be needed to view them, without the guarantee of observing informative and relevant structures. In the present study, a subfamily or tribe was tentatively proposed for only four of the adult specimens examined. Three of the specimens, Polyvena horatis (Dominican amber), Antiquatortia histuroides sp. nov. (Dominican amber) and Tortricidrosis inclusa (Baltic amber) show character combinations typical of Chlidanotinae (Polyorthini), a pantropical group with its greatest species richness in the Neotropical region. However, as mentioned previously, the monophyly of Chlidanotinae has been contested, and knowing the lineage (tribe) in which the fossil specimens belong would be necessary before using these fossils as calibration points in divergence time analyses. At present, the placement of the three fossils in tribes is only tentative, and the examination of genitalia would be necessary for a more reliable identification. Tortricites skalskii, in Baltic amber, is described to have labial palpi typical of Grapholitini (Olethreutinae), but in the absence of additional evidence this placement, although likely correct, cannot be confirmed.

The fossil record and the age of Tortricidae. The earliest evidence of Tortricidae comes from Baltic amber (Lutetian, Middle Eocene), reflecting the preservation bias in the fossil record of Lepidoptera - the vast majority being in Baltic amber (Sohn et al. 2015). Taking into account that relatively derived groups as Cochylini and Grapholitini (Regier et al. 2012; Fagua et al. 2017) possibly appear represented in this age, the stem of the group must be much older. In the divergence time estimate by Wahlberg et al. (2013) exploring the evolutionary history of all Lepidoptera, the median age of origin of Tortricoidea was estimated to be around $130 \mathrm{Ma}$. In a more recent divergence time analysis focusing on Tortricidae, the family was estimated to have diverged from its sister group (which is unresolved) ca. $120 \mathrm{Ma}$ and diversified c. $97 \mathrm{Ma}$, in concert with the rise of angiosperms in the early to mid-Cretaceous (Fagua et al. 2017). However, both analyses were based on unverified fossils. New analyses based on reliably identified fossils may provide more accurate estimates and allow the testing of the recent hypotheses presented by Fagua et al. (2017) regarding the effect of geological events on diversification, rate of diversification and biogeography of the tortricid lineages. An obstacle for such analyses and estimates is that the currently known fossil record of Tortricidae is extremely sparse, all specimens are relatively young and, as shown in this study, can be identified reliably to family level only.

The frequency with which Chlidanotinae (3 out of 11) are represented in the fossil record is completely unbalanced when compared to the current taxonomic ratios (370 species of Chlidanotinae out of ca 11000 described species of Tortricidae) (Gilligan et al. 2014). This situation, together with the difficulty in assigning the fossils of this subfamily in the present tribes, and the demonstrated paraphyly of the group full of generally plesiomorphic character states, suggest an original scenario different from the one of the present fauna. The extant clades currently considered in the subfamily Chlidanotinae would represent only what remains of the early diversification of the family, whereas the clades of the subfamilies Tortricinae and Olethreutinae may have originated later, coinciding with the decline of the first, a sequence of events similar to that presented in Fagua et al. (2017). Given the geographic isolation of some lineages of Tortricidae and groups represented, this early evolution had to occur no later than the Paleocene (Horak 1998, 2006).

At present, the fossil record of other groups of Lepidoptera does not provide much useful information on the age of Tortricidae either. The phylogenetic position of Tortricidae and their closest relatives are not known for certain (e.g. Mutanen et al. 2010; Regier et al. 2012; Kawahara \& Breinholt 2014; Timmermans et al. 2014; Heikkilä et al. 2015; Fagua et al. 2017). Also, the re-examination of fossils in other groups is still in progress and identifications in those families remain unverified. For example, the fossil record for Galacticidae, Heliocosmidae, Pterophoridae, Cossoidea, Zygaenoidea and Urodoidea, families placed close to Tortricidae in phylogenetic analyses, is also scarce, comprised mostly of relatively young fossils, and the identifications are questionable (Sohn et al. 2012).

There are fossil tortricids in Baltic and Dominican amber in private and museum collections that await description. Although we would hope that the material includes specimens that can be identified reliably to lower taxonomic levels, in the absence of genitalic characters, we are not optimistic. We encourage future workers to avoid "over-identification" but follow best practices and clearly justify and document the characters upon which their identifications and taxonomic placements are based. Detailed descriptions, especially of the morphology of 
the head, wing venation and pattern, scale tufts in different parts of the body, and genitalia would yield useful information about the evolution of characters even if they contribute little to estimating deep nodes of the phylogeny of the group. Finally, we regret that many specimens we hoped to re-examine during this study had been lost and that assessments had to be done based on the information provided in original descriptions and illustrations. The poor curation of several collections of fossil Lepidoptera adds to the inaccessibility of material and continues to hinder progress in this area.

\section{Acknowledgements}

We thank the following for helpful discussions, providing/editing photographs and allowing us to examine specimens in their care: David Grimaldi (American Museum of Natural History), Lauri Kaila (Finnish Museum of Natural History), Talia Karim (University of Colorado Museum of Natural History), Conrad Labandeira (Smithsonian Institution, NMNH), Crystal Maier (Field Museum of Natural History), Paul Mayer (Field Museum of Natural History), Mark Metz (USDA, ARS, Systematic Entomology Laboratory), David Notton (Natural History Museum, London), Thomas Pape (Natural History Museum of Denmark), Lukasz Przybyłowicz (Institute of Systematics and Evolution of Animals, Polish Academy of Sciences), Alexandr Rasnitsyn (Paleontological Institute, Russian Academy of Sciences), Courtney Richenbacher (American Museum of Natural History), Alan Rulis (Smithsonian Institution, NMNH), Jae-Cheon Sohn (Mokpo National University), Irina D. Sukacheva (Paleontological Institute, Russian Academy of Sciences), Ryszard Szadziewski (Gdańsk University), Marek Wanat (Museum of Natural History University of Wroclaw), David Zelagin (University of Colorado Museum of Natural History) and Vitali Zverev (University of Turku). The image of UCM 8579 was generated by the Fossil Insect Collaborative TCN. We are grateful to Marianne Horak, Giovanny Fagua and Rienk de Jong for their inspiring comments on an earlier draft of the manuscript. Funding for this study was provided by a Peter Buck Postdoctoral Fellowship at the NMNH, Smithsonian Institution (MH), Ella and Georg Ehrnrooth Foundation (MH), and Societas Entomologica Fennica (MH).

\section{References}

Bradley, J.D. (1957) Microlepidoptera from Rennell and Bellona Islands. The Natural History of Rennell Island, British Solomon Islands, 2 (19), 87-112.

Brown, J.W. (1990) Description of a new genus in the Chlidanotini and review of phylogenetic relationships among chlidanotine tribes (Lepidoptera: Tortricidae: Chlidanotinae). Entomologica Scandinavica, 20, 439-448. https://doi.org/10.1163/187631289X00429

Brown, J.W. (2005) World Catalogue of Insects. Vol. 5. Tortricidae (Lepidoptera). Stenstrup, Denmark., Apollo Books, 741 pp.

Carpenter, F.M. (1992) Superclass Hexapoda. In: Kaesler, R.L., Brosius, E., Keim, J. \& Priesner, J. (Eds.), Treatise on Invertebrate Paleontology. Part R (Arthropoda-4), 3 and 4 (Superclass Hexapoda). Geological Society of America and the University of Kansas, Boulder, Colorado and Lawrence, Kansas, xxi +655 pp.

Clemens, B. (1860) Contributions to American Lepidopterology. No. 6. Proceedings of the Academy of Natural Sciences of Philadelphia, 12, 345-362.

Cockerell, T.D.A. (1907) A fossil tortricid moth. The Canadian Entomologist, 39, 416. https://doi.org/10.4039/Ent39416-12

Cockerell, T.D.A. (1916) Some American fossil insects. Proceedings of the United States National Museum, 51 (2146), 89106. https://doi.org/10.5479/si.00963801.51-2146.89

Davis, D. (1998) The Monotrysian Heteroneura. In: Kristensen, N.P. (Ed.), Lepidoptera, Moths and Butterflies, 1 Evolution, systematics and biogeography. Handbuch der Zoologie/Handbook of Zoology 35. De Gruyter, Berlin, New York, pp. 6590. https://doi.org/10.1515/9783110804744.65

Davis, D.R. \& Gentili, P. (2003) Andesianidae, a new family of monotrysian moths (Lepidoptera : Andesianoidea) from austral South America. Invertebrate Systematics, 17 (1), 15-26. https://doi.org/10.1071/IS02006

de Jong, R. (2017) Fossil butterflies, calibration points and the molecular clock (Lepidoptera: Papilionoidea). Zootaxa, 4270 (1), $1-63$. https://doi.org/10.11646/zootaxa.4270.1.1 
Diakonoff, A. (1968) Microlepidoptera of the Philippine Islands. Bulletin of the United States National Museum, 257 (1967), 1-484.

Doorenweerd, C., Van Nieukerken, E.J., Sohn, J.C. \& Labandeira, C.C. (2015) A revised checklist of Nepticulidae fossils (Lepidoptera) indicates an Early Cretaceous origin. Zootaxa, 3963 (3), 295-334. https://doi.org/10.11646/zootaxa.3963.3.2

Fagua, G., Condamine, F.L., Horak, M., Zwick, A. \& Sperling, F.A.H. (2017) Diversification shifts in leafroller moths linked to continental colonization and the rise of angiosperms. Cladistics, 33 (5), 449-466. https://doi.org/10.1111/cla.12185

Gilligan, T.M., Baixeras, J., Brown, J.W. \& Tuck, K.R. (2014) T@RTS: Online World Catalogue of the Tortricidae. Version. 3.0. Available from: http://www.tortricid.net/catalogue.asp (accessed 13 June 2017)

Gravenhorst, J.L.C. (1835) Bericht der entomologischen Sektion. Schlesische Gesellschaft für Vaterländische Kultur Jahresbericht, 1984, 88-95.

Grimaldi, D. \& Engel, M.S. (2005) Amphiesmenoptera: The Caddisflies and Lepidoptera. In: Evolution of the Insects. Cambridge University Press, Cambridge, pp. 548-606.

Heikkilä, M., Mutanen, M., Wahlberg, N., Sihvonen, P. \& Kaila, L. (2015) Elusive ditrysian phylogeny: An account of combining systematized morphology with molecular data (Lepidoptera). BMC Evolutionary Biology, 15 (260), 1-27 https://doi.org/10.1186/s12862-015-0520-0

Horak, M. (1984) Assessment of taxonomically significant structures in Tortricinae (Lep., Tortricidae). Mitteilungen der Schweizerischen Entomologischen Gesellschaft, 57, 3-64.

Horak, M. (1998) The Tortricoidea. In: Kristensen, N.P. (Ed.), Lepidoptera, moths and butterflies, 1 Evolution, systematics and biogeography. Handbuch der Zoologie/Handbook of Zoology 35. Walter de Gruyter, Berlin, New York, pp. 199-215.

Horak, M. (2006) Olethreutine moths of Australia (Lepidoptera: Tortricidae) (Vol. 10), CSIRO Publishing, Victoria, 522 pp.

Horak, M. \& Brown, R.L. (1991) 1.2 Taxonomy and phylogeny. In: van der Geest, L.P.S. \& Evenhuis, H.H. (Eds.), Tortricid pests, their biology, natural enemies and control. Elsevier Science Publishers B.V., Amsterdam, pp. $23-48$.

Hübner, J. (1825) Verzeichnis bekannter Schmettlinge [sic]. bey dem Verfasser zu Finden, Augsburg, 432 pp. https://doi.org/10.5962/bhl.title.48607

ICZN (1999) International Code of Zoological Nomenclature. $4^{\text {th }}$ Edition. The International Trust for Zoological Nomenclature, London, 306 pp. Available from: http://www.iczn.org/iczn/index.jsp (Accessed 13 Mar. 2018)

Kawahara, A.Y. \& Breinholt, J.W. (2014) Phylogenomics provides strong evidence for relationships of butterflies and moths. Proceedings of the Royal Society B, 281, 20140970. https://doi.org/10.1098/rspb.2014.0970

Koponen, M. \& Nuorteva, M. (1973) Über subfossile Waldinsekten aus dem Moor Piilonsuo in Südfinnland. Acta Entomologica Fennica, 29, 1-84.

Kozlov, M.V. (1988) Paleontology of lepidopterans and problems of the phylogeny of the order Papilionida. In: Ponomarenko, A.G. (Ed.), The Mesozoic-Cenozoic Crisis in the Evolution of Insects. Nauka, Moscow, pp. 16-69.

Kozlov, M.V., Ivanov, V.D. \& Rasnitsyn, A.P. (2002) Order Lepidoptera Linné, 1758. The butterflies and moths. In: Rasnitsyn, A.P. \& Quicke, D.L.J. (Eds.), History of Insects. Kluwer Academic Publishers, Dordrecht, pp. 220-227.

Kristensen, N.P. \& Skalski, A.W. (1998) Phylogeny and palaeontology. In: Kristensen, N.P. (Ed.), Handbook of Zoology IV: Lepidoptera, moths and butterflies. Vol.1. Evolution, systematics and biogeography. Walter de Gruyter, Berlin, New York, pp. 7-25. https://doi.org/10.1515/9783110804744.7

Kusnezov, N.J. (1941) A revision of the amber Lepidoptera. Académie des Sciences de L’Union des Républiques Soviétiques Socialistes, Institut Paléontologique, Moscow \& Leningrad, 135 pp.

Labandeira, C. (2014) Amber. In: Laflamme, M., Schiffbauer, J.D. \& Darroch, S.A.F. (Eds.), Reading and Writing of the Fossil Record: Preservational Pathways to Exceptional Fossilization: Presented as a Paleontological Society Short Course at the Annual Meeting of the Geological Society of America, Vancouver, British Columbia, October 18, 2014. Paleontological Society, Boulder, Colorado, pp. 163-215.

Linnaeus, C. (1758) Systema naturae per regna tria naturae, secundum classes, ordines, genera, species, cum characteribus, differentiis, synonymis, locis. Editio decima, reformata, (1758-1759). Impensis Direct. Laurentii Salvii, Holmiae [Stockholm], $823 \mathrm{pp}$.

Menge, A. (1856) Lebenszeichen Vorweltlicher, im Bernstein Eingeschlossener Thiere. Programm der öffentlichen Prüfung der Schüler der Petrischule. A.W. Kafemann, Danzig, 32 pp.

Meyer, H.W. (2003) The Fossils of Florissant. Smithsonian Books, Washington D.C., 258 pp.

Meyrick, E. (1905) Descriptions of Indian Micro-Lepidoptera. Journal of the Bombay Natural History Society, 16 (4), $580-619$.

Mutanen, M., Wahlberg, N. \& Kaila, L. (2010) Comprehensive gene and taxon coverage elucidates radiation patterns in moths and butterflies. Proceedings of the Royal Society B, 277 (1695), 2839-2848. https://doi.org/10.1098/rspb.2010.0392

Parham, J.F., Donoghue, P.C.J., Bell, C.J., Calway, T.D., Head, J.J., Holroyd, P.A., Inoue, J.G., Irmis, R.B., Joyce, W.G., Ksepka, D.T., Patané, J.S.L., Smith, N.D., Tarver, J.E., Van Tuinen, M., Yang, Z., Angielczyk, K.D., Greenwood, J.M., Hipsley, C.A., Jacobs, L., Makovicky, P.J., Müller, J., Smith, K.T., Theodor, J.M., Warnock, R.C.M. \& Benton, M.J. (2012) Best practices for justifying fossil calibrations. Systematic Biology, 61 (2), 346-359. 
https://doi.org/10.1093/sysbio/syr107

Phillips-Rodriguez, E. \& Powell, J.A. (2007) Phylogenetic relationships, systematics, and biology of the species of Amorbia Clemens (Lepidoptera: Tortricidae: Sparganothini). Zootaxa, 1670, 1-109.

Poinar, G.O. (1992) Life in Amber. Stanford University Press, Stanford, 368 pp.

Poinar, G.O. \& Brown, J.W. (1993) A new fossil tortricid (Lepidoptera: Tortricidae) from Dominican amber. Entomologica Scandinavica, 23, 25-29. https://doi.org/10.1163/187631293X00028

Powell, J.A. \& Brown, J.W. (2012) Tortricoidea, Tortricidae (part): Tortricinae (part): Sparganothini and Atteriini. Wedge Entomological Research Foundation, Washington, D.C., 230 pp.

Powell, J.A., Mitter, C. \& Farrell, B.D. (1998) Evolution of larval feeding habits in Lepidoptera. In: Kristensen, N.P. (Ed.), Lepidoptera, moths and butterflies. 1. Evolution, systematics and biogeography. Handbuch der Zoologie/Handbook of Zoology 35. Walter de Gruyter, Berlin, New York, pp. 199-215.

Regier, J.C., Brown, J.W., Mitter, C., Baixeras, J., Cho, S., Cummings, M.P. \& Zwick, A. (2012) A molecular phylogeny for the leaf-roller moths (Lepidoptera: Tortricidae) and its implications for classification and life history evolution. PLoS ONE, 7 (4), e35574. https://doi.org/10.1371/journal.pone.0035574

Saalas, U. (1949) Suomen metsähyönteiset sekä muut metsälle vahingolliset ja hyödylliset eläimet. WSOY, Porvoo, Helsinki, $719 \mathrm{pp}$.

Skalski, A.W. (1973) Studies on the Lepidoptera from fossil resins. Part VI. Tortricidrosis inclusa gen. et spec. nov. from the Baltic amber (Lep., Tortricidae). Deutsche Entomologische Zeitschrift, 20, 339-344. https://doi.org/10.1002/mmnd.19730200406

Skalski, A.W. (1976) Les lépidoptères fossiles de l'ambre, État actuel de nos connaissances (2me partie). Linneana Belgica, 6 (8), 195-208.

Skalski, A.W. (1992) Studies on the Lepidoptera from fossil resins. Part III. Two new genera and species of Tortricidae from the Baltic amber. Annals of the Upper Silesian Museum in Bytom, Entomology, 3, 137-146.

Snellen, P.C.T. (1883) Nieuwe of weinig bekende Microlepidoptera von Noord-Azie, met afbeeldingen (Plaat 11, 12 en 13) door Dr. J. van Leeuwen Jr. ("Tortricina"). Tijdschrift voor Entomologie, 26, 181-228.

Sohn, J.-C., Labandeira, C., Davis, D. \& Mitter, C. (2012) An annotated catalog of fossil and subfossil Lepidoptera (Insecta: Holometabola) of the world. Zootaxa, 3286, 1-116.

Sohn, J.C. \& Lamas, G. (2013) Corrections, additions, and nomenclatural notes to the recently published World catalog of fossil and subfossil Lepidoptera. Zootaxa, 3599 (4), 395-399. https://doi.org/10.11646/zootaxa.3599.4.8

Sohn, J.-C., Labandeira, C. \& Davis, D. (2015) The fossil record and taphonomy of butterflies and moths (Insecta, Lepidoptera): implications for evolutionary diversity and divergence-time estimates. BMC Evolutionary Biology, 15 (12), $1-15$. https://doi.org/10.1186/s12862-015-0290-8

Timmermans, M.J.T.N., Lees, D.C. \& Simonsen, T.J. (2014) Towards a mitogenomic phylogeny of Lepidoptera. Molecular Phylogenetics and Evolution, 79, 169-178. https://doi.org/10.1016/j.ympev.2014.05.031

Treitschke, G.F. (1835) Die Schmetterlinge von Europa. Band 10/3. Fleisher, Leipzig, 302 pp.

Turnock, W.J. (1953) Some aspects of the life history and ecology of the pitch nodule maker, Petrova albicapitana (Busck) (Lepidoptera: Olethreutidae). Canadian Entomologist, 85, 233-243. https://doi.org/10.4039/Ent85233-7

Wahlberg, N., Wheat, C.W. \& Peña, C. (2013) Timing and patterns in the taxonomic diversification of Lepidoptera (butterflies and moths). PLOS ONE, 8 (11), e80875. https://doi.org/10.1371/journal.pone.0080875

Walker, F. (1863) List of the specimens of lepidopterous insects in the collection of the British Museum. Part XXVIII. Tortricites \& Tineites. British Museum (Natural History), London, $275 \mathrm{pp}$.

Yang, A. \& Brown, J.W. (2009) Variation in the female frenulum in Tortricidae (Lepidoptera). Part 1. Chlidanotinae. Proceedings of the Entomological Society of Washington, 111, 743-751. https://doi.org/10.4289/0013-8797-111.3.743

Zeller, P.C. (1877) Exotische Microlepidoptera. Horae Societatis Entomologicae Rossicae, 13, 3-493, 6 pls. 